\title{
Hyaluronidase Inhibitory Rosmarinic Acid Derivatives from Meehania urticifolia
}

\author{
Toshihiro Murata, ${ }^{*, a}$ Toshio Miyase, ${ }^{b}$ and Fumihiko Yoshizaki ${ }^{a}$ \\ ${ }^{a}$ Department of Pharmacognosy, Tohoku Pharmaceutical University; 4-4-1 Komatsushima, Aoba-ku, Sendai 981-8558, \\ Japan: and ${ }^{b}$ School of Pharmaceutical Sciences, University of Shizuoka; 52-1 Yada, Suruga-ku, Shizuoka 422-8526, \\ Japan. Received September 9, 2010; accepted October 3, 2010; published online October 8, 2010
}

\begin{abstract}
Nine new phenylpropanoids, rashomonic acids $A-D(1-4)$ and meehaniosides $A-E(5-9)$, along with four known compounds were isolated from Meehania urticifolia. The structure of each new compound was elucidated based on the results of spectroscopic analyses. Compounds $3-8$ showed moderate hyaluronidase inhibitory activity with $\mathrm{IC}_{50}$ values of $183-1049 \mu \mathrm{M}$.
\end{abstract}

Key words phenylpropanoid; rosmarinic acid; hyaluronidase inhibitor; Meehania urticifolia; Lamiaceae

Meehania urticifolia (MIQ.) MAKINo belongs to the family Lamiaceae. In the course of studying compounds from plants of the genus Meehania, we have identified spermidine alkaloidal glycosides, ${ }^{1,2}$ spermidine alkaloids, ${ }^{3)}$ and flavonoid glycosides. ${ }^{3)}$ Many phenylpropanoid oligomers and their derivatives, such as rosmarinic acid, have been found in Lamiaceae plants. ${ }^{4}$ In this paper, four new phenylpropanoids (14), and five new complexes of phenylpropanoid and phenylethanoid glycoside (5-9) were isolated along with rosmarinic acid (10), lithospermic acid B (11), conandroside (12), and vervascoside (13) from M. urticifolia. Compound $\mathbf{1 0}^{5)}$ and some of its derivatives ${ }^{3,6}$ have been recognized as hyaluronidase inhibitors, and $\mathbf{3}-\mathbf{8}$ also showed inhibitory activity. M. fargesii, which have been used to traditional Chinese medicine, have hyaluronidase inhibitory phenylpropanoids as well. ${ }^{3)}$

The methanol extract of whole specimens of M. urticifolia were dissolved in water and partitioned using ether. The water layer was fractionated by multistep column chromatography, and then $\mathbf{1}-\mathbf{9}$ were isolated, as pale yellowish amorphous powders. Known compounds were also isolated and identified from spectroscopic data as references $\left(\mathbf{1 0},{ }^{6)} \mathbf{1 1},{ }^{3)}\right.$ $12,{ }^{7)} 13^{8)}$ ).

Rashomonic acid A (1) was concluded to have the molecular formula $\mathrm{C}_{27} \mathrm{H}_{26} \mathrm{O}_{13}$ based on high resolution (HR)-FABMS ( $m / z 581.1255$, Calcd for $\left.\mathrm{C}_{27} \mathrm{H}_{26} \mathrm{O}_{13} \mathrm{Na}, 581.1270\right)$. The ${ }^{1} \mathrm{H}-\mathrm{NMR}$ and ${ }^{1} \mathrm{H}-{ }^{1} \mathrm{H}$ correlation spectroscopy (COSY) spectra of 1 showed the presence of two sets of ABX spin system protons and two singlet aromatic protons in the aromatic proton region, and three sets of methine-methylene protons in the aliphatic proton region (Table 1). The ${ }^{13} \mathrm{C}-\mathrm{NMR}$ spectrum of 1 showed the presence of three carboxyl carbons. In the nuclear Overhauser effect (NOE) spectra, a methine proton at $\delta 4.64$ (dd, $J=8.0,8.0 \mathrm{~Hz}, \mathrm{H}-7$ ) was found to be correlated with aromatic protons at $\delta 6.60(\mathrm{~d}, J=2.0 \mathrm{~Hz}, \mathrm{H}-2)$ and 6.45 (dd, $J=8.0,2.0 \mathrm{~Hz}, \mathrm{H}-6$ ), a methylene proton at $\delta 2.91$ (m, $\left.\mathrm{H}-7^{\prime}\right)$ was correlated with protons at $\delta 6.72(\mathrm{~d}, J=2.0 \mathrm{~Hz}, \mathrm{H}-$ $\left.2^{\prime}\right)$ and $6.55\left(\mathrm{dd}, J=8.0,2.0 \mathrm{~Hz}, \mathrm{H}-6^{\prime}\right)$, and methylene protons at $\delta 2.65\left(\mathrm{dd}, J=14.0,8.5 \mathrm{~Hz}, \mathrm{H}-7^{\prime \prime}\right)$ and $3.15(\mathrm{dd}$, $\left.J=14.0,4.5 \mathrm{~Hz}, \mathrm{H}-7^{\prime \prime}\right)$ were correlated with the aromatic singlet proton $(\delta 6.68, \mathrm{H}-2)$. These results showed that $\mathbf{1}$ has three phenylpropanoid moieties. In the heteronuclear multiple bond correlation (HMBC) spectrum, $\mathrm{H}-7$ was found to be correlated with C-1" ( $\delta$ 128.1), C-5" ( $\delta$ 115.3), and C-6" ( $\delta$
134.8 ); and $\mathrm{H}-8^{\prime}(\delta 4.98$, dd, $J=7.5,7.5 \mathrm{~Hz}$ ) was correlated with C-9 $(\delta$ 173.2). The absolute configurations of C-7 and $8^{\prime \prime}$ were determined as $7 R$ and $8^{\prime \prime} R$ from the retention time of the hydrolytic product of $\mathbf{1}$ and synthesized $1 \mathbf{a}\left(7 R, 8^{\prime} R\right)$ and 2a $\left(7 S, 8^{\prime} R\right)$. Both 1 and 1a showed positive Cotton effects around $240 \mathrm{~nm}$ in their circular dichroism (CD) spectra, which supported this conclusion. The absolute configuration of C-8' was determined to be $R$ from the retention time of the amide derivative of 3-(3,4-dihydroxyphenyl)-2-hydroxypropanoic acid, which was obtained by acidic hydrolysis of $\mathbf{1}$, in (S)-2-phenylglycine methyl ester. ${ }^{6}$ These results suggested that the structure of $\mathbf{1}$ was as shown in Fig. 1.

Rashomonic acid B (2) was concluded to have the molecular formula $\mathrm{C}_{27} \mathrm{H}_{26} \mathrm{O}_{13}$ based on HR-FAB-MS ( $m / z$ 557.1306, Calcd for $\mathrm{C}_{27} \mathrm{H}_{25} \mathrm{O}_{13}, 557.1295$ ). Its ${ }^{1} \mathrm{H}$ - and ${ }^{13} \mathrm{C}-\mathrm{NMR}$ spectra were similar to those of $\mathbf{1}$. The NOE and HMBC spectra suggested that $\mathbf{1}$ and $\mathbf{2}$ have the same planar configuration. After the acidic hydrolysis of $\mathbf{2}$, the absolute configurations of $\mathrm{C}-7,8^{\prime}$ and $8^{\prime \prime}$ were determined as $7 S, 8^{\prime} R$ and $8^{\prime \prime} R$ from the retention times of HPLC as in the case of 1 and a negative Cotton effect at $240 \mathrm{~nm}$ in the CD spectrum. The results suggested the structure of $\mathbf{2}$ to be as shown in Fig. 1.

The ${ }^{1} \mathrm{H}$ - and ${ }^{13} \mathrm{C}-\mathrm{NMR}$ spectra of $\mathbf{3}$ and $\mathbf{4}$ were similar to those of $\mathbf{1}$ and $\mathbf{2}$, respectively. They also suggested that $\mathbf{3}$ and 4 had another phenylpropanoid moiety. For $\mathbf{3}$, the molecular formula $\mathrm{C}_{36} \mathrm{H}_{32} \mathrm{O}_{16}$ was confirmed on the basis of HR-FABMS (m/z 721.1743, Calcd for $\left.\mathrm{C}_{36} \mathrm{H}_{33} \mathrm{O}_{16}, 721.1768\right)$. In the HMBC spectrum, a methine proton at $\delta 5.26(1 \mathrm{H}, \mathrm{dd}, J=9.0$, $\left.4.5 \mathrm{~Hz}, \mathrm{H}-8^{\prime \prime}\right)$ was found to be correlated with a carboxyl carbon at $\delta 168.8\left(\mathrm{C}-9^{\prime \prime \prime}\right)$. The absolute configurations of C-7, $8^{\prime}$ and $8^{\prime \prime}$ were determined to be $7 R, 8^{\prime} R$ and $8^{\prime \prime} R$ from the retention times of HPLC as in the case of $\mathbf{1}$. The CD spectrum was similar to that of $\mathbf{1}$, with positive Cotton effects of around $240 \mathrm{~nm}$. The structure of $\mathbf{3}$ was as shown in Fig. 1 . For 4, the molecular formula $\mathrm{C}_{36} \mathrm{H}_{32} \mathrm{O}_{16}$ was confirmed on the basis of HR-FAB-MS $(\mathrm{m} / \mathrm{z}$ 721.1786, Calcd for $\mathrm{C}_{36} \mathrm{H}_{33} \mathrm{O}_{16}, 721.1768$ ). The absolute configurations of $\mathrm{C}-7,8^{\prime}$ and $8^{\prime \prime}$ were determined as $7 S, 8^{\prime} R$ and $8^{\prime \prime} R$ from the retention times of HPLC as in the case of $\mathbf{2}$. The CD spectrum was similar to that of 2, with negative Cotton effects at around $240 \mathrm{~nm}$. The results suggested the structure of 4 to be as shown in Fig. 1.

Compound 5 showed a protonated ion peak at $\mathrm{m} / \mathrm{z}$ 839.2387 in the HR-FAB-MS analysis, which indicated the 


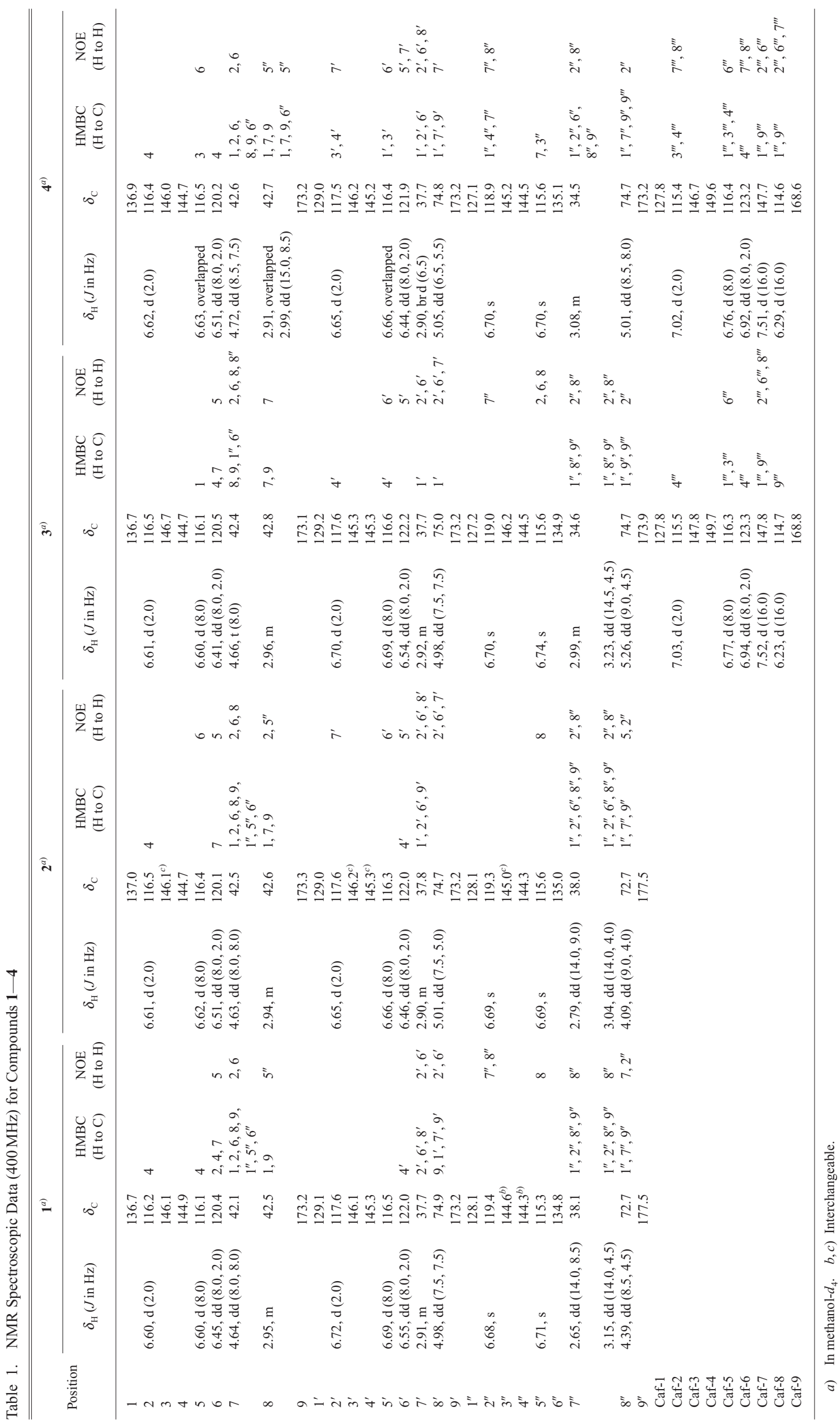




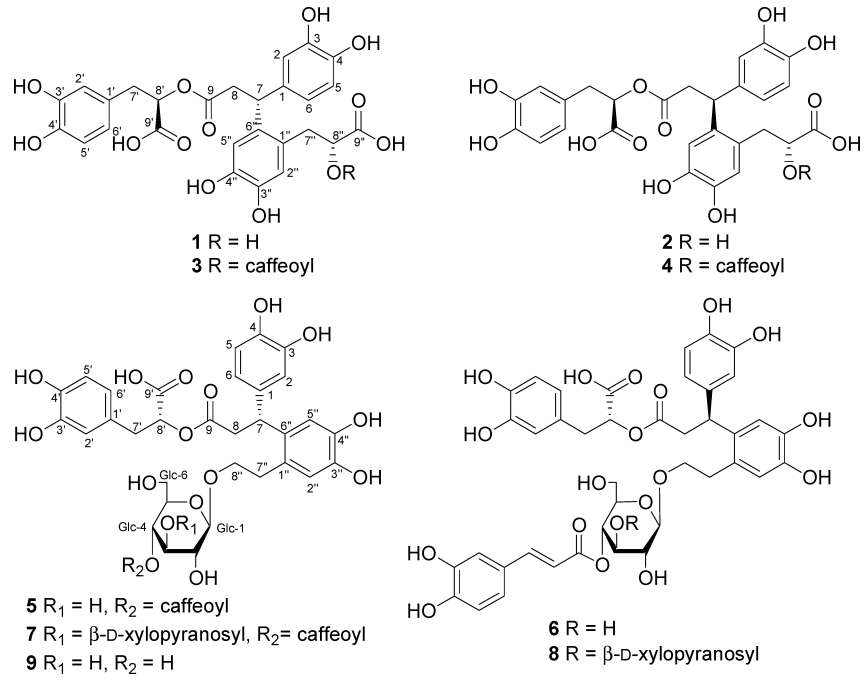

Fig. 1. Structures of $\mathbf{1}-\mathbf{9}$

molecular formula $\mathrm{C}_{41} \mathrm{H}_{42} \mathrm{O}_{19}$. The ${ }^{1} \mathrm{H}-\mathrm{NMR}$ and ${ }^{1} \mathrm{H}-{ }^{1} \mathrm{H}$ COSY spectra of $\mathbf{5}$ showed the presence of three sets of ABX spin system protons, two singlet aromatic protons, two sets of methine-methylene protons, and a set of ethylene protons (Table 2). The ethylene protons at $\delta 2.82(2 \mathrm{H}$, brt, $J=8.0 \mathrm{~Hz}$, H-7"), 3.37 (1H, m, H- $\left.8^{\prime \prime}\right)$, and 3.87 (1H, m, H- $\left.8^{\prime \prime}\right)$ suggested the presence of a phenylethanoid moiety. The H-7" proton was correlated with a singlet proton at $\delta 6.65$, and another singlet proton at $\delta 6.71$ correlated with $\mathrm{H}-7(\delta 4.47,1 \mathrm{H}$, brdd, $J=8.0,7.5 \mathrm{~Hz}$ ) in the NOE spectra. Two sets of ABX proton system protons and aliphatic protons including $\mathrm{H}-7$ showed the presence of a C-7 substituted rosmarinic acid moiety. An anomeric proton signal at $\delta 4.24(1 \mathrm{H}, \mathrm{d}$, $J=7.5 \mathrm{~Hz}$ ) and oxygenated carbons at $\delta 104.3,75.3,75.8$, $72.5,75.9$, and 62.3 suggested the presence of a glucose moiety. A sugar analysis and the coupling constant of the anomeric proton showed the presence of a $\beta$-D-glucose unit. ${ }^{9)}$ In the HMBC spectrum, a H-Glc-4 proton signal at $\delta 4.86$ $(1 \mathrm{H}, \mathrm{dd}, J=9.5,9.5 \mathrm{~Hz})$ was found to be correlated with a carboxyl carbon of the caffeic acid moiety at $\delta 168.7$ (C-9"'). The absolute configuration of $\mathrm{C}-7$ was concluded to be $R$ from the retention time of the hydrolytic product of $\mathbf{5}$ and synthesized 5a $(7 R)$ and $6 \mathbf{a}(7 S)$. Both $\mathbf{5}$ and $\mathbf{5 a}$ showed positive Cotton effects at around $240 \mathrm{~nm}$ in their CD spectra, which supported this conclusion. The absolute configuration of $\mathrm{C}-8^{\prime}$ was determined to be $R$ as in the case of 1 , in $(S)-2$ phenylglycine methyl ester. ${ }^{6}$. These results suggested the structure of $\mathbf{5}$ to be as shown in Fig. 1.

Compound $\mathbf{6}$ was a diastereomer of $\mathbf{5}$. The molecular formula $\mathrm{C}_{41} \mathrm{H}_{42} \mathrm{O}_{19}$ was confirmed on the basis of HR-FAB-MS ( $m / z$ 839.2410, Calcd for $\left.\mathrm{C}_{41} \mathrm{H}_{43} \mathrm{O}_{19}, 839.2398\right)$. The ${ }^{1} \mathrm{H}$ - and ${ }^{13} \mathrm{C}-\mathrm{NMR}$ spectra of $\mathbf{6}$ were similar to those of $\mathbf{5}$. The absolute configuration of C-7 was determined to be $S$ as in the case of 5. In the CD spectrum, a negative Cotton effect at around $240 \mathrm{~nm}$ was detected. The structure of $\mathbf{6}$ is shown in Fig. 1 .

The ${ }^{1} \mathrm{H}$ - and ${ }^{13} \mathrm{C}-\mathrm{NMR}$ spectra of 7 and $\mathbf{8}$ were similar to those of $\mathbf{5}$ and $\mathbf{6}$, respectively. However, they showed that 7 and 8 had a xylose moiety. The molecular formula $\mathrm{C}_{46} \mathrm{H}_{50} \mathrm{O}_{23}$ was revealed based on HR-FAB-MS $[\mathrm{m} / z$ 971.2817 (7) and $m / z 971.2813$ (8), Calcd for $\mathrm{C}_{46} \mathrm{H}_{51} \mathrm{O}_{23}, 971.2820$ ]. For 7, in the HMBC spectrum, the H-Glc-3 proton signal at $\delta 3.85$ ( $1 \mathrm{H}, \mathrm{dd}, J=9.5,9.0 \mathrm{~Hz}$ ) was found to be correlated with an anomeric carbon of the xylose moiety at $\delta$ 106.9. A sugar analysis and the coupling constant of the anomeric proton $(\delta$ $4.46,1 \mathrm{H}, \mathrm{d}, J=7.5 \mathrm{~Hz}$ ) showed the presence of a $\beta$-D-xylose unit. The absolute configurations of $\mathrm{C}-7$ and $\mathrm{C}-8^{\prime}$ were determined as $7 R$ and $8^{\prime} R$ by HPLC and the CD spectrum as in the case of 5 . These results suggested that the structure of 7 was as shown in Fig. 1. Compound $\mathbf{8}$ was a diastereomer of 7. The ${ }^{1} \mathrm{H}$ - and ${ }^{13} \mathrm{C}$-NMR spectra of $\mathbf{8}$ were similar to those of 7. The absolute configuration of $\mathrm{C}-7$ was concluded to be $S$ as in the case of 7 . In the CD spectrum, a negative Cotton effect around at $240 \mathrm{~nm}$ was detected. The structure of $\mathbf{8}$ is shown in Fig. 1.

The ${ }^{1} \mathrm{H}$ - and ${ }^{13} \mathrm{C}$-NMR spectra of 9 were similar to those of 5. The molecular formula $\mathrm{C}_{32} \mathrm{H}_{36} \mathrm{O}_{16}$ was established by HR-FAB-MS $\left(m / z \quad 699.1900\right.$, Calcd for $\mathrm{C}_{32} \mathrm{H}_{36} \mathrm{O}_{16} \mathrm{Na}$, 699.1900), which was $\mathrm{C}_{9} \mathrm{H}_{6} \mathrm{O}_{3}$ less than that of $\mathbf{5}$, indicating the absence of a caffeoyl moiety. The absolute configurations of $\mathrm{C}-7$ and $\mathrm{C}-8^{\prime}$ were concluded to be $7 R$ and $8^{\prime} R$ by the HPLC analyses and CD spectrum as in the case of 5 . The structure of 9 is shown in Fig. 1.

The absolute stereochemistry of C-7 in $\mathbf{1 a}, \mathbf{2 a}, \mathbf{5 a}$, and $\mathbf{6 a}$ was investigated by a modified version of the Mosher method for carboxylic acids having a chiral center at the $\beta$-position (Fig. 2). ${ }^{10)} \mathbf{1 b}$ and $\mathbf{2 b}$ were $(R)$-phenylglycine esters of $\mathbf{1 a}$ and $\mathbf{2 a}$, and $\mathbf{1} \mathbf{c}$ and $\mathbf{2 c}$ were $(S)$-phenylglycine esters of $\mathbf{1 a}$ and $\mathbf{2 a}$, respectively. The ${ }^{1} \mathrm{H}-\mathrm{NMR}$ chemical shift difference $[\Delta \delta$ $(\mathrm{ppm})=\delta \mathbf{1 b}-\delta \mathbf{1 c}]$ suggested that the absolute configuration of $\mathrm{C}-7$ in 1a was $R$ (Table 3 ). However, chemical shift differences $[\Delta \delta(\mathrm{ppm})=\delta \mathbf{2} \mathbf{b}-\delta \mathbf{2} \mathbf{c}]$ for C-7 in $\mathbf{2 a}$ were not applicable to this method (Table 3 ). The configuration of the C-7 in 2a was established as $S$, in the CD spectrum of $\mathbf{2 a}$ by comparison to that of $\mathbf{1 a}$ which has an opposite curve. $\mathbf{5 b}$ and $\mathbf{6 b}$ were $(R)$-phenylglycine methylester (PGME) esters of $\mathbf{5 a}$ and $\mathbf{6 a}$, and $\mathbf{5 c}$ and $\mathbf{6 c}$ were $(S)$-PGME esters of $\mathbf{5} \mathbf{a}$ and $\mathbf{6} \mathbf{a}$, respectively. The ${ }^{1} \mathrm{H}-\mathrm{NMR}$ chemical shift differences $[\Delta \delta$ $(\mathrm{ppm})=\delta \mathbf{5 b}-\delta \mathbf{5} \mathbf{c}]$ suggested that the absolute configuration of $\mathrm{C}-7$ in $\mathbf{5} \mathbf{a}$ was $R$, and $[\Delta \delta(\mathrm{ppm})=\delta \mathbf{6 b}-\delta \mathbf{6} \mathbf{c}]$ suggested that $\mathbf{6 a}$ had the $S$-configuration (Table 3 ).

Hyaluronidase inhibitory activity was measured for compounds $\mathbf{1}-\mathbf{8}, \mathbf{1 0}-\mathbf{1 3}, \mathbf{1 a}$, and $\mathbf{2 a}$ as shown in Table 4. Disodium cromoglycate (DSCG, Wako Pure Chemical Industries Ltd., Osaka, Japan; $\mathrm{IC}_{50} 297 \mu \mathrm{M}$ ) was used as a positive control. Rosmarinic acid dimers showed levels of activity $\left(\mathrm{IC}_{50}\right.$ 3: $\left.275 \mu \mathrm{M}, 4: 183 \mu \mathrm{M}\right)$ comparable to rosmarinic acid $\left(\mathrm{IC}_{50} 309 \mu \mathrm{M}\right)$, and phenylpropanoid monomers, caffeic acid and 3-(3,4)-dihydroxyphenyl)-2-hydroxy propanoic acid, had no activity. Although phenylethanoid glycosides $(\mathbf{1 2}, \mathbf{1 3})$ did not show inhibitory activity, complexes of rosmarinic acid and phenylethanoid glycosides (5-8) showed moderate levels of activity $\left(\mathrm{IC}_{50} 1049,873,924,781 \mu \mathrm{M}\right.$, respectively). Compounds $\mathbf{1 a}$ and $\mathbf{2 a}$ had no activity. These results suggested that the 3-(3,4-dihydroxyphenyl)-2-hydroxypropanoic acid moiety of oligomers was important to the hyaluronidase inhibitory activity.

\section{Experimental}

General Procedures Optical rotations were recorded on a Jasco P-2300 polarimeter. CD spectra were recorded on a Jasco J-700 spectropolarimeter; and UV, on a Shimadzu MPS-2450. ${ }^{1} \mathrm{H}-(400 \mathrm{MHz}),{ }^{13} \mathrm{C}-\mathrm{NMR}(100 \mathrm{MHz})$, ${ }^{1} \mathrm{H}-{ }^{1} \mathrm{H}$ COSY, heteronuclear multiple quantum correlation (HMQC) (opti- 


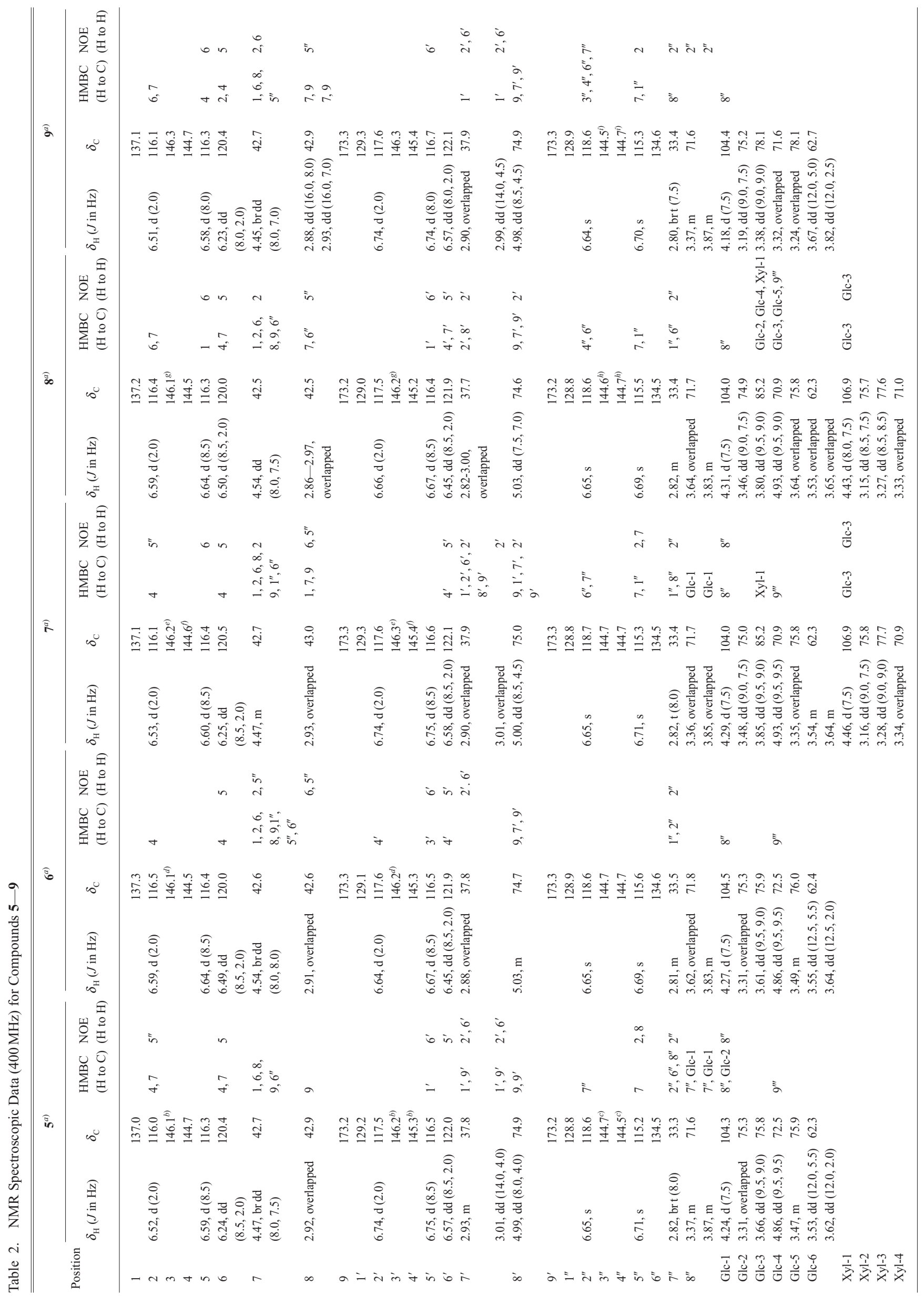




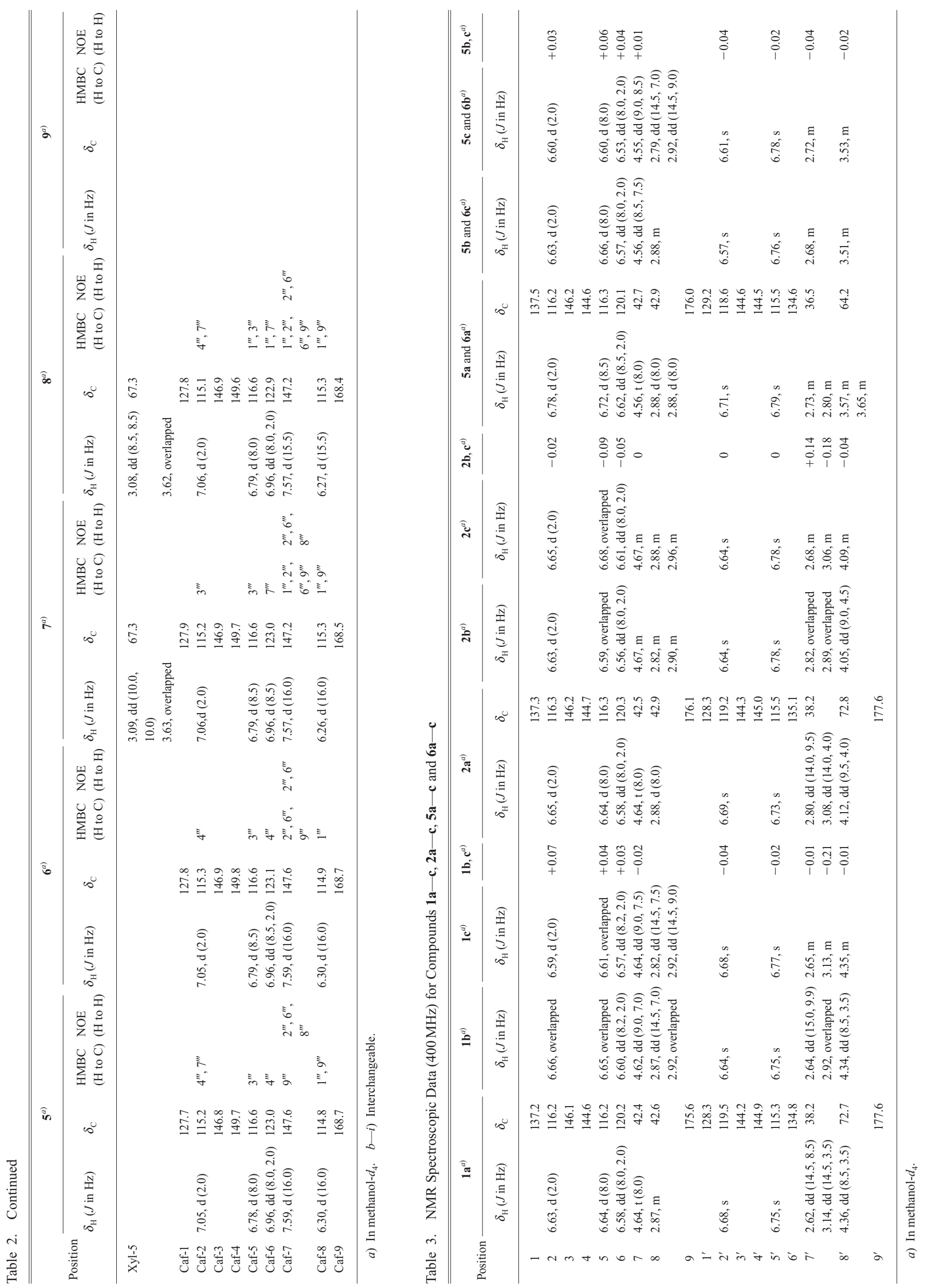




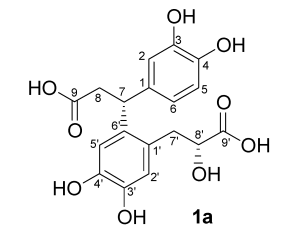<smiles>O=C(O)CC(c1ccc(O)c(O)c1)c1ccc(O)c(O)c1</smiles><smiles>COC(=O)C(NC(=O)/C=C/c1ccc(O)c(O)c1)c1ccccc1</smiles><smiles>COC(=O)C(NC(=O)/C=C/c1ccc(O)c(O)c1)c1ccccc1</smiles><smiles>O=C(C[C@H](c1ccc(O)c(O)c1)c1cc(O)c(O)cc1C[13C](=O)[18OH])N[C@@H](C(=O)O)c1ccccc1</smiles>
(S)-PGME-amide of caffeic acid<smiles>CC(=O)OC(=O)[C@H](Cc1cc(O)c(O)cc1[C@H](CC(=O)N[C@H](C(=O)O)c1ccccc1)c1ccc(O)c(O)c1)C(=O)O</smiles><smiles></smiles><smiles>O=C(O)CC(c1ccc(O)c(O)c1)c1cc(O)c(O)cc1CCO</smiles><smiles>COC(=O)[C@H](NC(=O)CC(c1ccc(O)c(O)c1)c1ccc(O)c(O)c1)c1ccccc1</smiles><smiles>COC(=O)[C@H](NC(=O)CC(c1ccc(O)c(O)c1)c1ccc(O)c(O)c1)c1ccccc1</smiles>

Fig. 2. Structure of Compounds for a Modified Version of the Mosher Method

Table 4. Hyaluronidase Inhibitory Activity of Compounds $\mathbf{1}-\mathbf{8}, \mathbf{1 0}-\mathbf{1 3}$, 1a, 2a, and DSCG

\begin{tabular}{cc}
\hline \hline Compound & $\mathrm{IC}_{50}(\mu \mathrm{M})$ \\
\hline $\mathbf{1}$ & N.D. $^{a)}$ \\
$\mathbf{2}$ & N.D. \\
$\mathbf{3}$ & 275 \\
$\mathbf{4}$ & 183 \\
$\mathbf{5}$ & 1049 \\
$\mathbf{6}$ & 873 \\
$\mathbf{7}$ & 924 \\
$\mathbf{8}$ & 781 \\
$\mathbf{1 0}$ & $309^{b)}$ \\
$\mathbf{1 1}$ & $164^{b)}$ \\
$\mathbf{1 2}$ & $\mathrm{N} . \mathrm{D}$. \\
$\mathbf{1 3}$ & N.D. \\
Caffeic acid & N.D. \\
3-(3,4-Dihydroxyphenyl)-2-hydroxypropanoic acid & N.D. \\
$\mathbf{1 a}$ & N.D. \\
$\mathbf{2 a}$ & N.D. \\
DSCG & $297^{b)}$ \\
\end{tabular}

a) Not determined. b) Previously reported value. ${ }^{3)}$

mized for ${ }^{1} J_{\mathrm{C}-\mathrm{H}}=145 \mathrm{~Hz}$ ) and HMBC (optimized for ${ }^{n} J_{\mathrm{C}-\mathrm{H}}=8 \mathrm{~Hz}$ ) spectra were recorded on a Jeol JNM-AL400 FT-NMR spectrometer, and chemical shifts were given as $\delta$ values with tetramethylsilane (TMS) as an internal standard. HR-FAB- and electron ionization-mass spectra (EI-MS) data were obtained on a Jeol JMS700 mass spectrometer, using a $m$-nitrobenzyl alcohol or a glycerol matrix. A porous polymer gel (Mitsubishi Chemical, Diaion HP-20, 60×300 mm) and octadecyl silica (ODS) (Cosmosil $140 \mathrm{C}_{18}$ OPN, Nacalai Tesque, Kyoto, Japan, $150 \mathrm{~g}$ ) were used for column chromatography. Preparative Yamazen Cartridge Column Chromatography (YCCC) was performed on a Jasco 2089 (column, Ultra Pack ODS-SM-
50C-M, Yamazen, $37 \times 100 \mathrm{~mm}$; detector, UV at $210 \mathrm{~nm}$ ). Preparative HPLC was performed on a Jasco 2089 and detected with UV at $210 \mathrm{~nm}$ (columns, ODS-100V, Tosoh, $20 \times 250 \mathrm{~mm}$; Capcell-Pak Ph, Shiseido, $20 \times 250 \mathrm{~mm}$; Cosmosil AR-II, Nacalai Tesque, $20 \times 250 \mathrm{~mm}$; Cosmosil 5PE-MS, Nacalai tesque, $20 \times 250 \mathrm{~mm}$ ).

Plant Material Meehania urticifolia was collected in July 2007 in Sendai, Japan. The plant was identified by Dr. Koji Yonekura, Tohoku University, Sendai, Japan. A voucher specimen has been deposited in the herbarium of Tohoku Pharmaceutical University, No. 20070727.

Extraction and Isolation Powdered whole specimens ( $760 \mathrm{~g}$ ) of $M$. urticifolia were extracted with methanol (121) twice at room temperature for a month. The methanol extract was concentrated at reduced pressure, suspended in water (1.51), and subjected to extraction with ether (1.01) three times. The aqueous layer $(98.5 \mathrm{~g})$ was dissolved in water and the solution was passed through a porous polymer gel (Mitsubishi Diaion HP-20, $70 \times 180 \mathrm{~mm}$ ) eluted with water, $10 \%, 45 \%$, and $90 \% \mathrm{MeOH}$ and $\mathrm{MeOH}$. The $45 \% \mathrm{MeOH}$ eluate $(5.1 \mathrm{~g})$ was chromatographed on a reversed-phase column using ODS (Cosmosil $140 \mathrm{C}_{18}$-OPN, Nacalai Tesque, $150 \mathrm{~g}$ ) eluting with $10 \%, 20 \%, 30 \%, 40 \%, 50 \%$ and $\mathrm{MeOH}$ (fractions $1 \mathrm{~A}-\mathrm{F}$ ). Fraction $1 \mathrm{C}$ $(1.3 \mathrm{~g})$ was subjected to preparative LPLC [solvent, methanol- $0.2 \%$ trifluoroacetic acid (TFA) $(35: 65)$ ], to give 10 fractions (Frs. 2A-J). Fractions 2B and $2 \mathrm{C}(220.6 \mathrm{mg})$ were subjected to preparative HPLC [column, Shiseido, Tokyo, Japan, Capcell-Pak Ph; solvent, acetonitrile- $0.2 \%$ TFA (12.5: 87.5)] to yield compounds $\mathbf{1}(7.7 \mathrm{mg}), \mathbf{2}(4.8 \mathrm{mg})$, and $\mathbf{9}(1.4 \mathrm{mg})$. Fractions 2D, 2E, $2 \mathrm{~F}$, and $2 \mathrm{G}(327.1 \mathrm{mg})$ were subjected to preparative HPLC [column, ODS100V; solvent, acetonitrile-water (25:75)], [column, Shiseido, Capcell-Pak $\mathrm{Ph}$; solvent, acetonitrile- $0.2 \%$ TFA $(20: 80)]$ to yield compounds 3 (13.0 mg), 4 (5.7 mg), 5 (5.1 mg), 6 (6.5 mg), 7 (10.6 mg), 8 (8.7 mg), 12 $(10.0 \mathrm{mg})$, and $\mathbf{1 3}(5.1 \mathrm{mg})$. Fraction $2 \mathrm{~J}(446.1 \mathrm{mg})$ was subjected to preparative HPLC [column, ODS-100V; solvent, acetonitrile- $0.2 \%$ TFA $(25: 75)$ ] to yield compounds $\mathbf{1 0}(52.4 \mathrm{mg})$ and $\mathbf{1 1}(73.5 \mathrm{mg})$.Rashomonic acid A (1): Colorless amorphous powder; $[\alpha]_{\mathrm{D}}^{22}-17.6(c=0.74, \mathrm{MeOH})$; UV $(\mathrm{MeOH})$ $\lambda_{\max }(\log \varepsilon) 285$ (4.58); $\mathrm{CD}(c=0.037, \mathrm{MeOH}) \lambda(\theta) 210(-48600), 242$ (17500), $294(-1700) \mathrm{nm} ;{ }^{1} \mathrm{H}$ - and ${ }^{13} \mathrm{C}-\mathrm{NMR}$, Table 1; HR-FAB-MS $\mathrm{m} / \mathrm{z}$ $581.1255[\mathrm{M}+\mathrm{Na}]^{+}\left(\right.$Calcd for $\left.\mathrm{C}_{27} \mathrm{H}_{26} \mathrm{O}_{13} \mathrm{Na}, 581.1270\right)$.

Rashomonic acid B (2): Colorless amorphous powder; $[\alpha]_{\mathrm{D}}^{23}+5.0$ $(c=0.44, \mathrm{MeOH}) ; \mathrm{UV}(\mathrm{MeOH}) \lambda_{\max }(\log \varepsilon) 285$ (4.63); CD $(c=0.022$, $\mathrm{MeOH}) \lambda(\theta) 226(100), 240(-19700), 261$ (4300), 276 (2100), 294 (7800) $\mathrm{nm}$; ${ }^{1} \mathrm{H}$ - and ${ }^{13} \mathrm{C}-\mathrm{NMR}$, Table 1; HR-FAB-MS $\mathrm{m} / \mathrm{z} 557.1306[\mathrm{M}-\mathrm{H}]^{-}$ (Calcd for $\mathrm{C}_{27} \mathrm{H}_{25} \mathrm{O}_{13}$, 557.1295).

Rashomonic acid C (3): Colorless amorphous powder; $[\alpha]_{\mathrm{D}}^{19}+27.7$ $(c=1.14, \mathrm{MeOH}) ; \mathrm{UV}(\mathrm{MeOH}) \lambda_{\max }(\log \varepsilon) 209$ (5.67), 288 (5.19), 331 (5.05); $\mathrm{CD}(c=0.057, \mathrm{MeOH}) \lambda(\theta) 242(22900), 284(100), 303(6300) \mathrm{nm}$; ${ }^{1} \mathrm{H}$ - and ${ }^{13} \mathrm{C}-\mathrm{NMR}$, Table 1; HR-FAB-MS $m / z 721.1743[\mathrm{M}+\mathrm{H}]^{+}$(Calcd for $\left.\mathrm{C}_{36} \mathrm{H}_{33} \mathrm{O}_{16}, 721.1768\right)$.

Rashomonic acid D (4): Colorless amorphous powder; $[\alpha]_{\mathrm{D}}^{21}+43.1$ $(c=0.58, \mathrm{MeOH}) ; \mathrm{UV}(\mathrm{MeOH}) \lambda_{\max }(\log \varepsilon) 203$ (5.92), 288 (5.22), 333 (5.08); $\mathrm{CD}(c=0.029, \mathrm{MeOH}) \lambda(\theta) 223(-800), 239$ (-28500), 257 (3800), 278 (100), 296 (13000) nm; ${ }^{1} \mathrm{H}-$ and ${ }^{13} \mathrm{C}-\mathrm{NMR}$, Table 1; HR-FAB-MS $\mathrm{m} / \mathrm{z}$ $721.1786[\mathrm{M}+\mathrm{H}]^{+}$(Calcd for $\left.\mathrm{C}_{36} \mathrm{H}_{33} \mathrm{O}_{16}, 721.1768\right)$.

Meehanioside A (5): Colorless amorphous powder; $[\alpha]_{\mathrm{D}}^{21}-13.2(c=0.44$, $\mathrm{MeOH}) ; \mathrm{UV}(\mathrm{MeOH}) \lambda_{\max }(\log \varepsilon) 205$ (5.83), 288 (5.22), 331 (5.10); CD $(c=0.029, \mathrm{MeOH}) \lambda(\theta) 211$ (-48400), 242 (16000), $287(-800), 304$ (4200) nm; ${ }^{1} \mathrm{H}-$ and ${ }^{13} \mathrm{C}-\mathrm{NMR}$, Table 2; HR-FAB-MS $\mathrm{m} / \mathrm{z} 839.2387$ $[\mathrm{M}+\mathrm{H}]^{+}$(Calcd for $\mathrm{C}_{41} \mathrm{H}_{43} \mathrm{O}_{19}, 839.2398$ ).

Meehanioside B (6): Colorless amorphous powder; $[\alpha]_{\mathrm{D}}^{22}-4.9(c=0.53$, $\mathrm{MeOH}) ; \mathrm{UV}(\mathrm{MeOH}) \lambda_{\max }(\log \varepsilon) 208$ (5.76), 289 (5.20), 331 (5.09); CD $(c=0.053, \mathrm{MeOH}) \lambda(\theta) 213(-9600), 226(-2700), 238(-12000), 255$ (3400), 276 (600), 295 (4800) nm; ${ }^{1} \mathrm{H}$ - and ${ }^{13} \mathrm{C}-\mathrm{NMR}$, Table 2; HR-FAB-MS $m / z 839.2410[\mathrm{M}+\mathrm{H}]^{+}$(Calcd for $\left.\mathrm{C}_{41} \mathrm{H}_{43} \mathrm{O}_{19}, 839.2398\right)$.

Meehanioside C (7): Colorless amorphous powder; $[\alpha]_{\mathrm{D}}^{20}-23.3(c=0.97$, $\mathrm{MeOH}) ; \mathrm{UV}(\mathrm{MeOH}) \lambda_{\max }(\log \varepsilon) 205$ (5.77), 289 (5.14), 330 (5.03); CD $(c=0.057, \mathrm{MeOH}) \lambda(\theta) 209$ (-61300), 241 (14500), $288(-1900), 303$ (2400) nm; ${ }^{1} \mathrm{H}-$ and ${ }^{13} \mathrm{C}-\mathrm{NMR}$, Table 2; HR-FAB-MS $\mathrm{m} / \mathrm{z} 971.2817$ $[\mathrm{M}+\mathrm{H}]^{+}$(Calcd for $\mathrm{C}_{46} \mathrm{H}_{51} \mathrm{O}_{23}, 971.2820$ ).

Meehanioside D (8): Colorless amorphous powder; $[\alpha]_{\mathrm{D}}^{21}-17.7(c=0.79$, $\mathrm{MeOH}) ; \mathrm{UV}(\mathrm{MeOH}) \lambda_{\max }(\log \varepsilon) 203$ (5.91), 289 (5.21), 330 (5.11); CD $(c=0.040, \mathrm{MeOH}) \lambda(\theta) 215(-9200), 225(-1600), 239(-14200), 262$ (3500), 276 (700), 294 (5300) nm; ${ }^{1} \mathrm{H}$ - and ${ }^{13} \mathrm{C}-\mathrm{NMR}$, Table 2; HR-FAB-MS $m / z 971.2813[\mathrm{M}+\mathrm{H}]^{+}\left(\right.$Calcd for $\left.\mathrm{C}_{46} \mathrm{H}_{51} \mathrm{O}_{23}, 971.2820\right)$.

Meehanioside E (9): Colorless amorphous powder; $[\alpha]_{\mathrm{D}}^{21}-26.7(c=0.12$, $\mathrm{MeOH}) ; \mathrm{UV}(\mathrm{MeOH}) \lambda_{\max }(\log \varepsilon) 286(5.00), 329$ (4.70); CD $(c=0.012$, $\mathrm{MeOH}) \lambda(\theta) 207(-75600), 240(23600) \mathrm{nm} ;{ }^{1} \mathrm{H}-$ and ${ }^{13} \mathrm{C}-\mathrm{NMR}$, Table 2; HR-FAB-MS $m / z$ 699.1900 [M+Na] ${ }^{+}$(Calcd for $\mathrm{C}_{32} \mathrm{H}_{36} \mathrm{O}_{16} \mathrm{Na}, 699.1900$ ). 
(R)-Phenylglycine Methyl Ester (PGME) Amide of Caffeic Acid: Colorless amorphous powder; $[\alpha]_{\mathrm{D}}^{19}-62.0 \quad(c=0.71, \mathrm{MeOH}) ;{ }^{1} \mathrm{H}-\mathrm{NMR}$ (methanol- $\left.d_{4}, 400 \mathrm{MHz}\right) \delta: 7.02(1 \mathrm{H}, \mathrm{d}, J=2.0 \mathrm{~Hz}, \mathrm{H}-2), 6.76(1 \mathrm{H}, \mathrm{d}$, $J=8.5 \mathrm{~Hz}, \mathrm{H}-5), 6.92(1 \mathrm{H}, \mathrm{dd}, J=8.5,2.0 \mathrm{~Hz}, \mathrm{H}-6), 7.43(1 \mathrm{H}, \mathrm{d}, J=16.0 \mathrm{~Hz}$, H-7), $6.52(1 \mathrm{H}, \mathrm{d}, J=16.0 \mathrm{~Hz}), 5.59(1 \mathrm{H}, \mathrm{s}, \mathrm{CH}), 7.30-7.45(5 \mathrm{H}, \mathrm{m}$, phenyl), $3.72(3 \mathrm{H}, \mathrm{s}, \mathrm{OMe}) ;{ }^{13} \mathrm{C}-\mathrm{NMR}$ (methanol- $\left.d_{4}, 100 \mathrm{MHz}\right) \delta: 138.2(\mathrm{C}-$ 1), 125.2 (C-2), 156.7 (C-3), 158.9 (C-4), 126.4 (C-5), 132.3 (C-6), 153.3 (C-7), 127.6 (C-8), 178.8 (C-9), $68.4(\mathrm{CH}), 182.7(\mathrm{C}=\mathrm{O}), 138.8,139.5$, 139.9, 147.5 (phenyl), 62.9 (OMe); EI-MS $m / z 327$.

$(S)$-PGME Amide of Caffeic Acid: Colorless amorphous powder; $[\alpha]_{\mathrm{D}}^{20}$ $+50.9(c=1.93, \mathrm{MeOH}) ;{ }^{1} \mathrm{H}-$ and ${ }^{13} \mathrm{C}-\mathrm{NMR}$, identical with $(R)$-PGME amide of caffeic acid; EI-MS $m / z 327$.

1a: Colorless amorphous powder; $[\alpha]_{\mathrm{D}}^{21}-30.5(c=1.24, \mathrm{MeOH})$; UV $(\mathrm{MeOH}) \lambda_{\max }(\log \varepsilon) 205$ (5.66), 287 (4.78); $\mathrm{CD}(c=0.012, \mathrm{MeOH}) \lambda(\theta)$ $206(-95900), 241(40800), 293(-3400) \mathrm{nm} ;{ }^{1} \mathrm{H}$ - and ${ }^{13} \mathrm{C}-\mathrm{NMR}$, Table 3; EI-MS $m / z 378$.

$(R)$-Phenylglycine Amide of 1a (1b): Colorless amorphous powder; $[\alpha]_{\mathrm{D}}^{20}$ $-41.9(c=0.43, \mathrm{MeOH}) ;{ }^{1} \mathrm{H}-\mathrm{NMR}$, Table 3; FAB-MS $m / z 513[\mathrm{M}+\mathrm{H}]^{+}$.

$(S)$-Phenylglycine Amide of 1a (1c): Colorless amorphous powder; $[\alpha]_{\mathrm{D}}^{20}$ $+10.3(c=0.58, \mathrm{MeOH}) ;{ }^{1} \mathrm{H}-\mathrm{NMR}$, Table 3; FAB-MS $m / z 513[\mathrm{M}+\mathrm{H}]^{+}$.

2a: Colorless amorphous powder; $[\alpha]_{\mathrm{D}}^{21}+31.8(c=1.39, \mathrm{MeOH})$; UV $(\mathrm{MeOH}) \lambda_{\max }(\log \varepsilon) 206$ (5.66), 287 (4.79); $\mathrm{CD}(c=0.014, \mathrm{MeOH}) \lambda(\theta)$ 205 (13500), 240 (-34200), 294 (10100) nm; ${ }^{1} \mathrm{H}-$ and ${ }^{13} \mathrm{C}-\mathrm{NMR}$, Table 3; EI-MS $m / z 378$.

$(R)$-Phenylglycine Amide of 2a (2b): Colorless amorphous powder; $[\alpha]_{\mathrm{D}}^{20}$ $-12.6(c=0.57, \mathrm{MeOH}) ;{ }^{1} \mathrm{H}-\mathrm{NMR}$, Table 3; FAB-MS $m / z 513[\mathrm{M}+\mathrm{H}]^{+}$.

$(S)$-Phenylglycine Amide of $2 \mathbf{a}(\mathbf{2 c})$ : Colorless amorphous powder; $[\alpha]_{\mathrm{D}}^{20}$ $+37.4(c=0.46, \mathrm{MeOH}) ;{ }^{1} \mathrm{H}-\mathrm{NMR}$, Table 3; FAB-MS m/z $513[\mathrm{M}+\mathrm{H}]^{+}$.

5a: Colorless amorphous powder; $[\alpha]_{\mathrm{D}}^{20}-44.3(c=0.14, \mathrm{MeOH})$; UV $(\mathrm{MeOH}) \lambda_{\max }(\log \varepsilon) 208$ (5.47), 287 (4.78); $\mathrm{CD}(c=0.028, \mathrm{MeOH}) \lambda(\theta)$ 207 (-54300), 240 (26400), $293(-4700) \mathrm{nm} ;{ }^{1} \mathrm{H}$ - and ${ }^{13} \mathrm{C}-\mathrm{NMR}$, Table 3; EI-MS $m / z 334$

(R)-PGME Amide of $\mathbf{5 a}(\mathbf{5 b})$ : Colorless amorphous powder; $[\alpha]_{\mathrm{D}}^{20}-55.5$ $(c=0.71, \mathrm{MeOH}) ;{ }^{1} \mathrm{H}-\mathrm{NMR}$, Table 3; EI-MS $m / z 481$.

$(S)$-PGME Amide of $\mathbf{5 a}(\mathbf{5 c})$ : Colorless amorphous powder; $[\alpha]_{\mathrm{D}}^{20}-14.3$ $(c=0.70, \mathrm{MeOH}) ;{ }^{1} \mathrm{H}-\mathrm{NMR}$, Table 3; EI-MS $m / z 481$.

6a: Colorless amorphous powder; $[\alpha]_{\mathrm{D}}^{20}+41.8(c=0.11, \mathrm{MeOH})$; UV $(\mathrm{MeOH}) \lambda_{\max }(\log \varepsilon) 207$ (5.52), 287 (4.75); CD $(c=0.022, \mathrm{MeOH}) \lambda(\theta)$ 205 (91000), $240(-18700), 292(7600) \mathrm{nm} ;{ }^{1} \mathrm{H}-$ and ${ }^{13} \mathrm{C}-\mathrm{NMR}$, Table 3; EIMS $m / z 334$.

$(R)$-PGME Amide of $\mathbf{6 a}(\mathbf{6 b})$ : Colorless amorphous powder; $[\alpha]_{\mathrm{D}}^{20}+56.1$ $(c=0.82, \mathrm{MeOH}) ;{ }^{1} \mathrm{H}-\mathrm{NMR}$, Table 3; EI-MS $m / z 481$.

$(S)$-PGME Amide of $\mathbf{6 a}(\mathbf{6 c})$ : Colorless amorphous powder; $[\alpha]_{\mathrm{D}}^{20}+13.5$ $(c=0.65, \mathrm{MeOH}) ;{ }^{1} \mathrm{H}-\mathrm{NMR}$, Table 3; FAB-MS $m / z 482[\mathrm{M}+\mathrm{H}]^{+}$

Acidic Hydrolysis of Compounds $\mathbf{1}-\mathbf{9}$ Each compound [ $\mathbf{1}(2.6 \mathrm{mg}), \mathbf{2}$ $(1.0 \mathrm{mg}), \mathbf{3}(2.6 \mathrm{mg}), \mathbf{4}(1.1 \mathrm{mg}), \mathbf{5}(2.5 \mathrm{mg}), \mathbf{6}(1.3 \mathrm{mg}), 7(5.4 \mathrm{mg}), \mathbf{8}$ $(1.5 \mathrm{mg})$, and $9(0.4 \mathrm{mg})]$ was dissolved in $7 \% \mathrm{HCl}(1 \mathrm{ml})$ and stirred for $2 \mathrm{~h}$ at $60^{\circ} \mathrm{C}$. After concentration, the residue of $\mathbf{1}$ and $\mathbf{3}$ was subjected to preparative HPLC [column, Capcell-Pak Ph; solvent, acetonitrile- $0.2 \%$ TFA $(10: 90)]$ to yield 1a and 3-(3,4-dihydroxyphenyl)-2-hydroxypropanoic acid. The residue of compounds $\mathbf{2}$ and $\mathbf{4}$ was subjected to preparative HPLC [column, Capcell-Pak Ph; solvent, acetonitrile-0.2\% TFA (10:90)], yielding 2a and 3-(3,4-dihydroxyphenyl)-2-hydroxypropanoic acid. The residue of compounds 5-9 was subjected to preparative HPLC [column, Capcell-Pak Ph; solvent, acetonitrile- $0.2 \%$ TFA $(10: 90)$ ] to yield $5 \mathbf{a}$ or $\mathbf{6 a}, 3$-(3,4-dihydroxyphenyl)-2-hydroxypropanoic acid, and a sugar fraction.

(S)-PGME and (R)-PGME Esters of 3-(3,4-Dihydroxyphenyl)-2-hydroxypropanoic Acid To $2 R$-3-(3,4-dihydroxyphenyl)-2-hydroxypropanoic acid (5 mg, each) obtained from rosmarinic acid ${ }^{6}$ in $N, N$-dimethylformamide (DMF) $(1.0 \mathrm{ml})$ was added $(S)$-PGME or $(R)$-PGME $(10 \mathrm{mg})$, and then benzotriazol-1-yl-oxy-tris-pyrrolidinophonium hexafluorophosphate (PyBOP) (15 mg), 1-hydroxybenzotriazole (HOBt) (5 mg), and $N$-methylmorpholine $(20 \mu \mathrm{l})$ were added and the mixture was stirred for $10 \mathrm{~h}$ at room temperature. The reactions gave $(S)$-amide and $(R)$-amide. ${ }^{6}$ The retention time of $(S)$-amide was $14.9 \mathrm{~min}$ and that of $(R)$-amide was $15.4 \mathrm{~min}$. The analytical HPLC was performed on a Shiseido Capcell Pak Ph column $(4.6 \times 250 \mathrm{~mm})$ using acetonitrile $-0.2 \%$ TFA in water $(15: 85)$ as the solvent (flow rate, $1 \mathrm{ml} / \mathrm{min}$; detector, UV $210 \mathrm{~nm}$ ). The retention time of $(S)$-PGME esters of 3-(3,4-dihydroxyphenyl)-2-hydroxypropanoic acid obtained from the acid hydrolysis of $\mathbf{1}-\mathbf{9}$ was $14.9 \mathrm{~min}$.

Determination of the Stereochemistry of 1a and 2a Acid hydrolysis of rosmarinic acid (11) (300 mg) gave 3-(3,4-dihydroxyphenyl)-2-hydroxypropanoic acid $(72.8 \mathrm{mg})$, and compounds $\mathbf{1 a}(11.9 \mathrm{mg})$ and $\mathbf{2 a}(13.4 \mathrm{mg}) .3-$ (3,4-Dihydroxyphenyl)-2-hydroxypropanoic acid $(20 \mathrm{mg})$ and caffeic acid
$(60 \mathrm{mg})$ were dissolved in dioxan $(10 \mathrm{ml})$ and added to $p$-toluenesulfonic acid, then stirred for $3 \mathrm{~h}$ at $100{ }^{\circ} \mathrm{C}$. After cooling, the reaction mixture was concentrated and subjected to preparative HPLC [column, Capcell-Pak Ph; solvent, acetonitrile- $0.2 \%$ TFA $(10: 90)]$ to yield compounds $1 \mathrm{a}(6.8 \mathrm{mg})$ and $\mathbf{2 a}(5.1 \mathrm{mg})$. The retention time of $\mathbf{1 a}$ was $8.40 \mathrm{~min}$ and that of $\mathbf{2 a}$ was $7.75 \mathrm{~min}$ [the analytical HPLC was performed on a Cosmosil AR-II column $(4.6 \times 250 \mathrm{~mm})$ using acetonitrile- $0.2 \%$ TFA in water $(10: 90)$ as the solvent (flow rate, $1 \mathrm{ml} / \mathrm{min}$; detector, UV $210 \mathrm{~nm}$ )]. To caffeic acid $(160 \mathrm{mg}$ ) in DMF $(6 \mathrm{ml})$ was added $(R)$-PGME $(200 \mathrm{mg})$ or $(S)$-PGME $(200 \mathrm{mg})$, and then HOBt $(200 \mathrm{mg})$, and $N$-methylmorpholine $(300 \mu \mathrm{l})$ were added and the mixture was stirred for $10 \mathrm{~h}$ at room temperature. The reactions gave the $(R)$ PGME-amide of caffeic acid $(53.2 \mathrm{mg})$ and $(S)$-PGME-amide of caffeic acid $(49.6 \mathrm{mg})$. The $(R)$-PGME-amide of caffeic acid $(15 \mathrm{mg})$ and 3-(3,4-dihydroxyphenyl)-2-hydroxypropanoic acid $(15 \mathrm{mg})$ were dissolved in $7 \% \mathrm{HCl}$ $(5 \mathrm{ml})$ and stirred for $1.5 \mathrm{~h}$ at $60^{\circ} \mathrm{C}$. After cooling, the reaction mixture was concentrated and subjected to preparative HPLC [column, Capcell-Pak Ph; solvent, acetonitrile- $0.2 \%$ TFA $(10: 90)]$ to yield compounds $\mathbf{1 b}(2.8 \mathrm{mg})$ and $\mathbf{2 b}(2.9 \mathrm{mg})$. The $(S)$-PGME-amide of caffeic acid $(30 \mathrm{mg})$ and $3-(3,4-$ dihydroxyphenyl)-2-hydroxypropanoic acid $(30 \mathrm{mg})$ were dissolved in $7 \%$ $\mathrm{HCl}(5 \mathrm{ml})$ and stirred for $1.5 \mathrm{~h}$ at $60^{\circ} \mathrm{C}$. After cooling, the reaction mixture was concentrated and subjected to preparative HPLC [column, Capcell-Pak $\mathrm{Ph}$; solvent, acetonitrile-0.2\% TFA $(10: 90)]$, yielding $1 \mathrm{c}(6.0 \mathrm{mg})$ and $2 \mathrm{c}$ $(4.6 \mathrm{mg})$. Acid hydrolysis $\left(7 \% \mathrm{HCl}, 3 \mathrm{~h}, 100^{\circ} \mathrm{C}\right)$ of $\mathbf{1 b}$ and $\mathbf{1 c}$ gave $\mathbf{1 a}$. Acid hydrolysis $\left(7 \% \mathrm{HCl}, 3 \mathrm{~h}, 100^{\circ} \mathrm{C}\right)$ of $\mathbf{2 b}$ and $\mathbf{2 c}$ gave $\mathbf{2 a}$.

Determination of the Stereochemistry of 5a and 6a 2-(3,4-Dihydroxyphenyl) ethyl alcohol $(200 \mathrm{mg})$ (Tokyo Chemical Industry Co., Ltd., Tokyo, Japan) and caffeic acid $(150 \mathrm{mg})$ were dissolved in $7 \% \mathrm{HCl}(5 \mathrm{ml})$ and stirred for $3 \mathrm{~h}$ at $80^{\circ} \mathrm{C}$. After cooling, the reaction mixture was concentrated and subjected to preparative HPLC [column, Capcell-Pak Ph; solvent, acetonitrile- $0.2 \%$ TFA $(10: 90)$ ] to yield a mixture of $\mathbf{5 a}$ and $\mathbf{6 a}(59.8 \mathrm{mg})$. To the mixture of $\mathbf{5 a}$ and $\mathbf{6 a}(27.2 \mathrm{mg})$ in DMF $(3 \mathrm{ml})$ were added $(R)$-PGME $(60 \mathrm{mg}), \mathrm{HOBt}(30 \mathrm{mg})$, and $N$-methylmorpholine $(100 \mu \mathrm{l})$ and the solution stirred for $10 \mathrm{~h}$ at room temperature. The solution was concentrated and subjected to preparative HPLC [columns, Cosmosil AR-II and Cosmosil 5PEMS; solvent, acetonitrile- $0.2 \%$ TFA $(25: 75)]$ to yield $(R)$-PGME-amide of $5 \mathbf{a}(\mathbf{5 b}, 11.4 \mathrm{mg})$ and $(R)$-PGME-amide of $\mathbf{6 a}(\mathbf{6} \mathbf{b}, 10.0 \mathrm{mg})$. To the mixture of $5 \mathbf{a}$ and $\mathbf{6 a}(32.6 \mathrm{mg})$ in DMF $(3 \mathrm{ml})$ were added $(S)$-PGME $(60 \mathrm{mg})$, HOBt $(30 \mathrm{mg})$, and $N$-methylmorpholine $(100 \mu \mathrm{l})$ and the mixture stirred for $10 \mathrm{~h}$ at room temperature. The solution was concentrated and subjected to preparative HPLC [columns, Cosmosil AR-II and Cosmosil 5PE-MS; solvent, acetonitrile- $0.2 \%$ TFA $(25: 75)]$ to yield $(S)$-PGME-amide of $\mathbf{5 a}(\mathbf{5 c}$, $11.5 \mathrm{mg}$ ), and $(S)$-PGME-amide of $\mathbf{6 a}(\mathbf{6 c}, 12.7 \mathrm{mg})$. Acid hydrolysis $(7 \%$ $\left.\mathrm{HCl}, 3 \mathrm{~h}, 100^{\circ} \mathrm{C}\right)$ of $\mathbf{5 b}$ and $\mathbf{5 c}$ gave $\mathbf{5 a}(1.1 \mathrm{mg})$. Acid hydrolysis $(7 \% \mathrm{HCl}$, $\left.3 \mathrm{~h}, 100^{\circ} \mathrm{C}\right)$ of $6 \mathbf{b}$ and $6 \mathbf{c}$ gave $6 \mathbf{a}(0.9 \mathrm{mg})$.

CD Spectra of the Products of Acidic Hydrolysis of 5-9, 5a, and 6a Each complex of caffeic acid and 3-(3,4-dihydroxyphenyl)-2-hydroxypropanoic acid obtained by the acid hydrolysis of compounds 5 , 7, and 9 showed a positive Cotton effect at $240 \mathrm{~nm}$, identical to 5a. Each complex of caffeic acid and 3-(3,4-dihydroxyphenyl)-2-hydroxypropanoic acid obtained by acid hydrolysis of $\mathbf{6}$ and $\mathbf{8}$ showed a negative Cotton effect at $240 \mathrm{~nm}$, identical to $\mathbf{6 a}$.

Sugar Identification Sugar fractions from 5-9 were dissolved in pyridine (each $0.5 \mathrm{ml})$ and stirred with L-cysteine methyl ester $(5 \mathrm{mg})$ before $o$ tolyl isothiocyanate $(20 \mu \mathrm{l})$ was added to the mixture using the same procedures as in our previous report. ${ }^{1}$ The reaction mixtures were analyzed by HPLC and detected at $250 \mathrm{~nm}$. Analytical HPLC was performed on a Cosmosil AR-II column $(4.6 \times 250 \mathrm{~mm})$ at $25^{\circ} \mathrm{C}$ using $\mathrm{CH}_{3} \mathrm{CN}-0.2 \%$ TFA in $\mathrm{H}_{2} \mathrm{O}(25: 75)$ as the solvent. Peaks were detected with a Tosoh UV8010 detector. D-Glucose $\left(t_{\mathrm{R}} 15.5 \mathrm{~min}\right)$ and D-xylose $\left(t_{\mathrm{R}} 17.7 \mathrm{~min}\right)$ were identified as the sugar moieties of $\mathbf{5}-\mathbf{9}(\mathbf{5}, \mathbf{6}, \mathbf{9}$ were only D-glucose) by comparing their retention times with those of authentic samples of D-glucose $\left(t_{\mathrm{R}} 15.5 \mathrm{~min}\right)$, Lglucose $\left(t_{\mathrm{R}} 14.1 \mathrm{~min}\right)$, D-xylose $\left(t_{\mathrm{R}} 17.7 \mathrm{~min}\right)$, and L-xylose $\left.\left(t_{\mathrm{R}} 16.5 \mathrm{~min}\right){ }^{10}\right)$

Assay of Hyaluronidase Inhibition The assay was carried out according to the Morgan-Elson method, which was modified by Davidson and Aronson. ${ }^{5,11,12)}$ Each compound (final concentration: 1, 0.3, 0.1,0.03 mM) was dissolved in $0.1 \mathrm{M}$ acetate buffer as the sample solution. Hyaluronidase activity was measured as described previously. ${ }^{3,6}$ DSCG was used as a positive control. The final concentration of hyaluronidase was $400 \mathrm{unit} / \mathrm{ml}$.

Acknowledgments We thank Mr. S. Sato and Mr. T. Matsuki, Tohoku Pharmaceutical University for assisting with the MS measurements and Mr. H. Hayasaka and K. Ohba of the Department of Experimental Station for Medicinal Plant Studies, Tohoku University, for supplying the plant material. 


\section{References}

1) Murata T., Miyase T., Warashina T., Yoshizaki F., J. Nat. Prod., 72, 1049-1056 (2009).

2) Murata T., Miyase T., Yoshizaki F., J. Nat. Prod., 72, 1937-1943 (2009).

3) Murata T., Miyase T., Yoshizaki F., Chem. Pharm. Bull., 58, 696-702 (2010).

4) Petersen M., Simmonds M. S. J., Phytochemistry, 62, 121-125 (2003).

5) Ippoushi K., Yamaguchi Y., Itou H., Azuma K., Higashio H., Food Sci. Technol. Res., 6, 74-77 (2000).
6) Murata T., Watahiki M., Tanaka Y., Miyase T., Yoshizaki F., Chem. Pharm. Bull., 58, 394-397 (2010).

7) Jensen S. R., Phytochemistry, 43, 777-783 (1996)

8) Sakurai A., Kato T., Bull. Chem. Soc. Jpn., 56, 1573-1574 (1983).

9) Yabuuchi T., Kusumi T., J. Org. Chem., 65, 397-404 (2000).

10) Tanaka T., Nakashima T., Ueda T., Tomii K., Kouno I., Chem. Pharm. Bull., 55, 899-901 (2007).

11) Reissig J. L., Strominger J. L., Leloir L. F., J. Biol. Chem., 217, 959966 (1955).

12) Aronson N. N., Davidson E. A., J. Biol. Chem., 242, 437-440 (1967). 